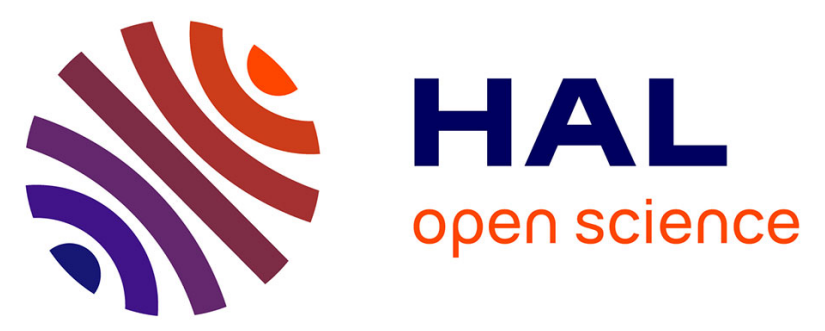

\title{
3D models related to the publication: Neotropics provide insights into the emergence of New World monkeys: new dental evidence from the late Oligocene of Peruvian Amazonia
}

Laurent Marivaux, Rodolfo Salas-Gismondi, Pierre-Olivier Antoine

\section{To cite this version:}

Laurent Marivaux, Rodolfo Salas-Gismondi, Pierre-Olivier Antoine. 3D models related to the publication: Neotropics provide insights into the emergence of New World monkeys: new dental evidence from the late Oligocene of Peruvian Amazonia. MorphoMuseum, 2017, 3 (1), 10.18563/m3.3.1.e1. hal-01813187

\author{
HAL Id: hal-01813187 \\ https://hal.umontpellier.fr/hal-01813187
}

Submitted on 13 Jun 2018

HAL is a multi-disciplinary open access archive for the deposit and dissemination of scientific research documents, whether they are published or not. The documents may come from teaching and research institutions in France or abroad, or from public or private research centers.
L'archive ouverte pluridisciplinaire HAL, est destinée au dépôt et à la diffusion de documents scientifiques de niveau recherche, publiés ou non, émanant des établissements d'enseignement et de recherche français ou étrangers, des laboratoires publics ou privés. 


\title{
3D models related to the publication: Neotropics provide insights into the emergence of New World monkeys: new dental evidence from the late Oligocene of Peruvian Amazonia
}

\author{
Marivaux Laurent ${ }^{1 *}$, Salas-Gismondi Rodolfo ${ }^{2}$, Antoine Pierre-Olivier ${ }^{1}$ \\ ${ }^{1}$ Laboratoire de Paléontologie, Institut des Sciences de l'Évolution de Montpellier (ISE-M, UMR 5554, CNRS/UM/IRD/EPHE), c.C. 064, \\ Université de Montpellier, place Eugène Bataillon, 34095 Montpellier Cedex 05, France \\ ${ }^{2}$ Departamento de Paleontología de Vertebrados, Museo de Historia Natural - Universidad Nacional Mayor San Marcos (MUSM), Av. Arenales \\ 1256, Lima 11, Peru \\ *Corresponding author: laurent.marivaux@umontpellier.fr
}

\section{Abstract}

This contribution contains the 3D models of the isolated teeth of Canaanimico amazonensis, a new stem platyrrhine primate, described and figured in the following publication: Marivaux et al. (2016), Neotropics provide insights into the emergence of New World monkeys: new dental evidence from the late Oligocene of Peruvian Amazonia. Journal of Human Evolution. http://dx.doi.org/10.1016/j.jhevol.2016.05.011

Keywords: Homunculidae, Paleogene, Peru, Soriacebinae, South America

Submitted:2017-08-14, published online:2017-09-13. https://doi.org/10.18563/m3.3.1.e1

\section{INTRODUCTION}

We present here the 3D digital models of the fossils documenting Canaanimico amazonensis Marivaux et al. 2016, a medium-sized platyrrhine monkey, recently found in Peruvian Amazonia (Contamana, Loreto Department) from fluvial deposits (CTA-61) dating from the late Oligocene (ca. 26.5 Ma; i.e., Deseadan South American Land Mammal Ages [SALMA]; Antoine et al., 2016). This anthropoid primate is known by only two isolated upper teeth (Fig. 1; Table 1) recovered after wet-screening of more than $800 \mathrm{~kg}$ of sediment. MUSM-2500 is the lingual part of a pristine left M1, which was probably broken during the fossilization process. MUSM-2499 is a complete left M2, which is particularly well-preserved aside from minor wear to the apices of the main cusps due to occlusal attrition during the life of the animal. From our comparative dental analysis, we have seen that Canaanimico exhibits a few upper molar characters that are otherwise found only in a limited group of platyrrhines. However, most other characters may be found individually in extinct or/and living taxa belonging either to the Pitheciidae, Cebidae or Atelidae. In order to investigate and formalize the phylogenetic position of Canaanimico in a high-level platyrrhine phylogeny, we have performed a cladistic assessment of the dental evidence. The results strengthen support for the soriacebine affinities of Canaanimico among the early Miocene 'Homunculidae', a group of stem platyrrhines placed outside the crown platyrrhine radiation. Canaanimico therefore extends back the soriacebine lineage to $26.5 \mathrm{Ma}$. This discovery adds to the evidence that platyrrhines were well established in western Amazonia during mid-Cenozoic times (see Marivaux et al., 2016).

$\begin{array}{lll}\text { Model IDs } & \begin{array}{c}\text { Taxon } \\ \text { Canaanimico } \\ \text { amazonensis }\end{array} & \begin{array}{l}\text { Description } \\ \text { Left upper M2 } \\ \text { (Holotype) }\end{array} \\ \text { MUSM-2500 } & \begin{array}{l}\text { Canaanimico } \\ \text { amazonensis }\end{array} & \begin{array}{l}\text { left upper M1 } \\ \text { (lingual part) }\end{array}\end{array}$

Table 1. List of models. All specimens come from the Museo de Historia Natural - Universidad Nacional Mayor San Marcos (MUSM), Lima, Peru.

\section{METHODS}

AVIZO 7.1 (Visualization Sciences Group) software was used for visualization, segmentation and $3 \mathrm{D}$ rendering. The teeth were prepared within a "labelfield" module of AVIZO, using the segmentation threshold selection tool. The 3D models are provided in .ply format, and then can be opened with a wide range of freeware.

\section{ACKNOWLEDGEMENTS}

3D data presented in this work were produced through the technical facilities of the Montpellier RIO Imaging (MRI) platform and of the LabEx CeMEB. We particularly thank R. Lebrun (ISE-M, Université de Montpellier) for his help and advices during micro-CT scan acquisitions and treatments. This work (paleontological fieldwork and laboratory post-field analyses) was financially supported by the L. S. B. Leakey Foundation. This work has also benefited from an "Investissements d'Avenir" grant managed by the Agence Nationale de la Recherche, France (CEBA, ANR-10-LABX-0025-01). 


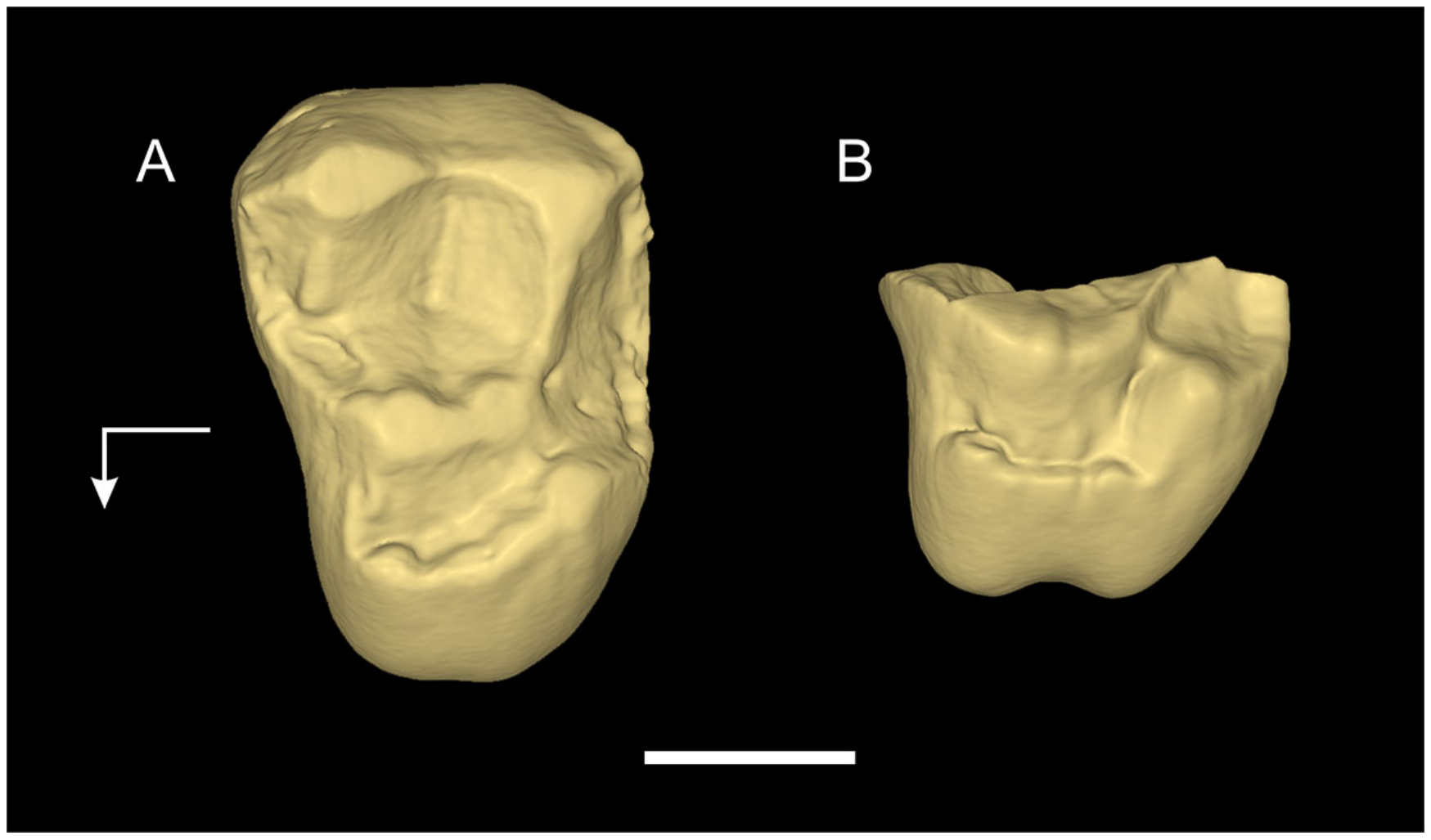

Figure 1. Fossil dental specimens of Canaanimico amazonensis Marivaux et al. 2006, from the late Oligocene (Deseadan SALMA) of Contamana locus n ${ }^{\circ} 61$ (CTA-61), Peruvian Amazonia. A) MUSM-2499, left M2 in occlusal view; B) MUSM-2500, left M1 in occlusal view. The white arrow situated on the left indicate the orientation of the teeth on the jaws (i.e., mesiolingual). Scale bar $=2 \mathrm{~mm}$.

\section{BIBLIOGRAPHY}

Antoine, P.-O., Abello, M. A., Adnet, S., Altamirano-Sierra, A. J., Baby, P., Billet, G., Boivin, M., Calderón, Y., Candela, A. M., Chabain, J., Corfu, F., Croft, D. A., Ganerød, M., Jaramillo, C., Klaus, S., Marivaux, L., Navarrete, R. E., Orliac, M. J., Parra, F., Pérez, M. E., Pujos, F., Rage, J.C., Ravel, A., Robinet, C., Roddaz, M., Tejada-Lara, J. V., Vélez-Juarbe, J., Wesselingh, F. P., Salas-Gismondi, R., 2016. A 60-million year Cenozoic history of western Amazonian ecosystems in Contamana, Eastern Peru. Gondwana Research 31, 30-59. http://dx.doi.org/10.1016/j.gr.2015.11.001

Marivaux, L., Adnet, S., Altamirano-Sierra, A. J., Boivin, M., Pujos, F., Ramdarshan, A., Salas-Gismondi, R., Tejada-Lara, J. V., Antoine, P.-O., 2016. Neotropics provide insights into the emergence of New World monkeys: new dental evidence from the late Oligocene of Peruvian Amazonia. Journal of Human Evolution 97, 159-175. http://dx.doi.org/10.1016/j.jh evol.2016.05.011 